\title{
Rescue of Jews in France 1940-44: The Jesuit Contribution
}

\author{
Limore Yagil \\ Sorbonne University, Paris \\ ylimore@yahoo.fr
}

\begin{abstract}
Until recently, most Holocaust historians have devoted little attention to the topic of Jesuit priests who gave Jews shelter and helped them, in defiance of the orders of Vichy Government or the Germans authorities. In order to understand how it was possible for about 250,00o Jews in France, not to be deported, and to find help among the population, it is important also to take into account the activities of Jesuits providing hiding places for several hundred children and also adults. Most of them were able to obey their conscience, and disobey orders, and to act illegally in order to rescue Jews. Rescuers were not working alone, but generally they developed networks including also non-religious people. Above all, this study reveals us how much it was important to accomplish rescue in a collaborative group of rescuers: the network. This study also reveals much about the modalities of rescuing Jews in France in different regions. Most Catholic rescuers had been engaged before the war in a spiritual and theological way with anti-Nazi activities, especially in helping refugees, and in resistance to antiSemitism and racism. It was indeed the Catholics, and especially the Jesuits and Dominicans, who raised the most attention regarding the Nazi danger, and this prepared them to act in rescuing Jews after 1940 in France.
\end{abstract}

\section{Keywords}

Rescue of Jews - righteous gentiles - Holocaust - France - Second War World German occupation in France - civil disobedience - resistance 
It is recognized by most historians that only a quarter of the Jews of France were deported (totaling 76,000 out of a population of about 310,000). ${ }^{1}$ On the one hand the Germans, with the assistance of the actively anti-Semitic Vichy government and of a certain number of actively anti-Semitic French citizens, deported a shocking number of the Jews living in France between 1940 and 1944 to their deaths. On the other hand, the proportion of Jews deported from France was much smaller than that deported from Netherlands, Belgium, or Norway. Is it not surprising that among the Nazi-dominated countries of Western Europe the country reputedly most anti-Semitic had one of the highest survival rates? The answer of this French "paradox" is the assistance giving by French individuals, or by voluntary organizations, both Jewish and non-Jewish. In my books, I have proposed detailed analysis concerning those individuals who have disobeyed orders, laws, and instructions given by German authorities and the Vichy regime in order to rescue Jews. Civil disobedience can be understood as the individual reaction to a situation that is no longer tolerable. We can find social workers, nurses in hospitals, doctors, teachers and educators, policemen and civil servants such as prefects (the prefect is the head of a department), secretaries of prefecture, artists, priests, pastors, bishops, and religious sisters. Rescue activities took many forms and included hiding people, helping them escape, and providing false identities, food, and shelter. These activities had to be carried out in secret, there was always the risk of being discovered. Rescuers who were caught were arrested and sent to concentration camps and prisons and many were killed. In this article, we are essentially interested in Jesuit priests and their help to Jews in France during the occupation period. This article is based on documented accounts and archives material concerning the rescue activities of Catholics in France. ${ }^{2}$

1 François et Renée Bédarida, "La persécution des Juifs," in Jean Pierre Azéma and François Bédarida, eds., La France des années noires (Paris: Seuil, 1992), 2:128-52; Asher Cohen, Persécutions et sauvetages: Juifs et français sous l'occupation et sous Vichy (Paris: Le Cerf, 1993); André Kaspi, Les Juifs pendant l'occupation (Paris: Seuil, 1991); Limore Yagil, Chrétiens et Juifs sous Vichy 1940-1944: Sauvetage et désobéissance civile (Paris: Cerf, 2005); Yagil, La France terre de refuge et de désobéissance civile 1936-1944: Sauvetage des Juifs, 3 vols. (Paris: Cerf, 2010-11).

2 Archives Nationales (AN); Archives des Jésuites, Vanves (AJ); Archives diocésaines (AD); Yad Vashem, Righteous among the Nations Archive (serie M31); Archives diocésaines de Paris: Fond Cardinal Suhard (ADP); Archives Départementales (AD): Vienne, Indre-et-Loire; Sarthe; Mayenne; Toulouse; Vaucluse; Marseille; Centre de Documentation Juif Contemporain, Paris (CDJC). 


\section{Situation of France in 1940}

The rapidity with which the German armed forces overran all of Western Europe between April and June 1940 came as a massive shock. It is difficult to characterize the chaos that was France in the days and weeks surrounding the armistice. In the short term, nothing was fixed. The towns and cities of the north remembering the occupation and conditions of the First World War emptied rapidly. Following the French capitulation in June 1940, France was divided into two main zones: the one occupied by the Germans and centered on Paris, and the other, unoccupied, where nominally the French writ still ran freely, and which eventually centered on Vichy. During the July 10, 1940 meeting at Vichy spa's casino, the National assembly entrusted the aged Marshal Pétain (1856-1951) with full powers to govern until he had drawn up a new constitution. The Third Republic was presumed dead and only eighty deputies mourned its passing. The one exception was the church, whose hierarchical organization was still intact and whose influence had increased. The hierarchy took the lead in backing Pétain, insisting that he could save France as he had in 1916. By the autumn of 1940, messages of support flowed in from all sections of the church.

In 1940-41, the church was hand in glove with the regime, dazzled by the glory in which Pétain basked and convinced of the need for the national reform. It reviewed uncritically controversial measures such as the anti-Masonic, anti-Communist and xenophobic legislation, including the first Statute of the Jews, and some churchmen even regarded them with benevolence. In offering full support to the "National Revolution" regime installed by Marshal Pétain, and for fear of endangering the Vichy program of restoration of the country, the Catholic hierarchy refrained from protesting against the unjust decree punishing the French Jews and kept silent. They maintained the same silence when the foreign Jews (October 4, 1940) were shamefully confined in "special camps" of evil character.

The Statut des Juifs of October 1940 overthrew Republican values by targeting French Jews, who suffered various restrictions. Vichy also treated foreign Jews (and other refugees) as particularly undesirable, interning them and readily handing them over to the Germans when asked. From 1941, Vichy collaborated with the gathering Nazi extermination of European Jews, especially as regarding "foreign Jews" on French soil.

At that time, approximately 320,000 Jews lived in France, some of whom were refugees from Germany and other countries occupied by the Nazis. including thousands of children. Almost immediately after the occupation, Jews living in the occupied zone and those in the unoccupied zone were subjected 
to the first wave of anti-Jewish measures. In the German-controlled zone, Jews were stripped of their jobs, their freedom of movement became restricted, and many were arrested. At the same time, the Vichy government actively began to persecute the Jewish community, and in October 1940, a set of laws called the Statut des Juifs was passed. The discriminatory regime inflicted on Jews did not disturb the majority of French people before the big round-ups of summer 1942, but there was anti-Semitism and xenophobia in the public opinion, which was manifested as soon as the pressure of the occupier or the government increased the sacrifices demanded. In the early days, the emotion raised by the tribulations to which the Jews were subjected gave rise to different initiatives in order to help Jews. Protestants like Roland de Pury (1907-79) and Charles Westphal (1896-1972), who adhered to the Theses of Pomeyrol, were condemning openly anti-Semitism and the dangers of collaboration with the Germans. (The Theses of Pomeyrol constituted a statement drafted by Protestants on September 16-17, 1941 that dealt with the relationship between church and state and affirmed the right of the church to speak out publicly. Pomeyrol was the name of a French retreat center that was located in southern France.)

Along with others Protestants, Pastor Marc Boegner (1891-1970), president of the Fédération Protestante, was among the first religious leaders to protest against Vichy's anti-Jewish legislation. Robert Paxton says the first clear opposition to anti-Semitism comes from Protestants. ${ }^{3}$ But in fact some isolated prelates, Jesuits, Dominicans, nuns, and other religious began to act as individuals in order to resist anti-Semitism and Nazism. ${ }^{4}$

In our study of wartime rescuers of Jews in France, sociologically we can find much variety of character and motivation. Some rescuers acted from specific compassion for Jews, while others were anti-Semitic. Some tended to the right in their politics, while others were left-wing. But all or nearly all rescuers

3 Michael R. Marrus and Robert O. Paxton, Vichy France and the Jews (New York: Basic Books, 1981), 203-8. See also, Philip Hallie, Lest Innocent Blood Be Shed (London: Harper Perennial, 1979).

4 About this aspect see Yagil, Chrétiens et Juifs sous Vichy and Yagil, La France terre de refuge. A selected bibliography concerning the church and Vichy: Jacques Duquesne, Les Catholiques français sous l'Occupation (Paris: Grasset 1966); Henri Fabre, L'Église catholique face au fascisme et au nazisme: Les outrages à la vérité (Bruxelles, E.P.O. 1994); Michèle Cointet, L'Église sous Vichy 1940-1945: La repentance en question (Paris: Perrin, 1998); Renée Bédarida, Les Catholiques dans la guerre 1939-1945 (Paris: Hachette, 1998); Jean Louis Clément, Les Évêques au temps de Vichy (Paris: Beauchesne, 1998). Bernard Comte, L'Honneur et la conscience: Catholiques français en résistance, 1940-1944 (Paris: L'Atelier, 1998); W.D. Halls, Politics, Society and Christianity in Vichy France (Oxford: Berg French Studies, 1995); Sylvie Bernay, L'Église de France face à la persécution des juifs 1940-1944 (Paris: CNRS, 2012); Jean-Marie Lustiger, Le Choix de Dieu (Paris: Éditions de Fallois, 1987): 104-6. 
demonstrated extreme individualism, independent thinking, and a capacity to disobey orders in rescuing Jews. In Poland, for example, the Catholic Church was anti-Semitic and had no uniform wartime policy regarding the Jews. Without a papal decree or a national Catholic stance, individuals within the clergy and laity alike were on their own regarding the rescue of Jews. ${ }^{5}$

The role of the major Christian denominations, their leaders, clerics, and congregations in helping Jews has been much discussed. Given the hierarchical nature of the Catholic Church, the attitudes and behavior of its leading prelates could determine the extent of help for Jews in particular regions. Those attitudes were, however, highly ambivalent. In fact, helping Jews did not signify that the person was becoming philo-Semitic. Generally, Catholic attitudes towards Jews were largely determined by local considerations and local leaders. Moreover, most of them condemned the arrest and deportations of Jews while at the same time reaffirming loyalty to Marshal Pétain, head of the government of Vichy. Influence towards practical help was limited to private advice to both clergy and lay people within particular dioceses to support Jews in hiding. Individual prelates could also exercise influence over individual monasteries, convents, seminaries, welfare, and educational institutions even when these were not directly controlled by the diocese. ${ }^{6}$ Moreover, their names could be invoked in order to encourage the laity to co-operate in sheltering Jews. Although most of them had condemned Nazism and racism, most leaders of the Catholic Church welcomed Pétain with great enthusiasm.

Just as they had in the 188 os and 1890 s, those leaders still criticized the Third Republic, with its separation of the churches from the states, its dissolution of religious orders, and its banning of religious in the public schools. Because they hoped the Vichy regime would restore some of the privileges of the church, particularly in the field of education, they were willing to overlook abuses. The church continued its policy of respecting the government of the moment, as recommended by the Vatican. The official church position was that the hierarchy would be loyal to the established regime but not in thrall to it. The ACA (Assemblée des Cardinaux et Archevêques, an assembly of the archbishops and cardinals) met in September 1941 and issued a reminder to priests not to

5 Nechama Tec, When Light Pierced the Darkness: Christian Rescue of Jews in Nazi-Occupied Poland (Oxford: Oxford University Press, 1986); Samuel P. Oliner, The Altruistic Personality: Rescuers of Jews in Nazi Europe (New York: Free Press; London, 1988); Eva Fogelman, Conscience and Courage: The Rescuers of the Jews during the Holocaust (New York: Doubleday, 1994); Gilbert, Martin, The Righteous: The Unsung Heroes of the Holocaust (New York: Henry Holt and Company, 2003).

6 Yagil, Chrétiens et Juifs; Yagil, La France terre de refuge. There were about forty-five bishops in France who were involved in rescuing Jews in their dioceses. This is an important conclusion. All the research is based on archival materials. 
be involved in activities of a political nature, such as contributing to the spread of government propaganda. It forbade priests and leaders of Catholic movements to hold office in the association of First World War veterans (the Légion Française des Combattants), created by Vichy after it had disbanded all previous veterans' associations. On July 24, 1941, the ACA declared the Vichy regime "legitimate." The Vichy regime was a representative institution, having been actually voted in by the assembled Parliament at a time of the gravest crisis. There were members of the clergy, especially at the beginning, who sympathized with the Vichy regime. They liked Petain's message: repenting sins, restoring authority and discipline, returning to the land and to the family. They liked Vichy's motto: Travail, Famille, Patrie (work, family, country). Loyalty to Vichy regime was progressively being put to the test. The promulgation of the first statute on the Jews and, following almost immediately, the internment of foreign Jews, coupled with Petain's meeting with Adolf Hitler (1889-1945) at Montoire on October 24, upset many Christians, as indeed other Frenchmen.

\section{Lyon and the Jesuit Scholasticate Fourvière}

For more than four centuries the Jesuits had marked Lyon with their presence. Although the Jesuits were not recognized civilly in France until 1562, its members were studying at Paris as early as 1540. They were influential as educators, because of their many colleges, and they served as advisers and confessors to the French kings. After the Great War, when a number of Jesuits in Lyon were represented, the Society experienced a second period of approbation, summed up by a place name: Fourvière. With its Catholic faculties, the Jesuit Scholasticate Fourvière, the interdiocesan seminary, but also the Catholic teachers at the university, Lyon's influence extended far beyond the borders of the country. Since 1932, the Fourvière was known as a prestigious school of theology in French Catholicism. With the start of World War II, at least 780 Jesuits from four French provinces of the Society of Jesus were called into military service. By the time the armistice was signed on June 22,1940, three fifths of France had fallen to the Germans. The French Jesuits had lost twenty-one members on the field of battle. Many others were kept in captivity and were transported into German territory without food and shelter. Although some were returned as a result of illness and others were able to escape, there were still 120 in captivity in Germany sixteen months later.

Father Victor Dillard (1897-1945) is perhaps the best known of the French Jesuits who became involved in severe criticism of the regime. Père Dillard, who died on January 12, 1945 in Dachau, was a frequent preacher at St-Louis in Vichy, a fashionable church of the establishment, but also spoke against 
Nazism. A native of Blois in the Loire region, he was twenty-two when he entered the Society of Jesus. Trained as a sociologist, Dillard was deeply involved in social issues and became disillusioned with the Vichy government for failing to effect the restoration of France.

As soon as the new regime was installed, the provincials of the Society of Jesus chose "presence," that is to say, in accordance with Catholic doctrine, obedience to the established power. It serves the "common good" in not diverting believers from Christian demands. In fact, the Society of Jesus had many supporters in Vichy: its former students and alumni of student groups are particularly well represented at the head of youth movements, in the General Secretariat for Youth (SGJ), surrounding Marshal Pétain (including Henry du Moulin de Labarthète [1900-45], Henri Dhavernas [1912-2009], Charles Vallin [1903-48], Pierre Goutet (1903-90), Charles Célier [1912-92]). It also had a strong ally within the episcopate in the person of Cardinal Pierre-Marie Gerlier (1880-1965), archbishop of Lyon. The Society very early had demonstrated great loyalty to the new regime and, as historians Dominique Avon and Philippe Rocher have noted: "loyalty to Marshal Petain is continuously asserted at the top of the Society until 1943." After the defeat of 1940, the Jesuits of Popular Action, a movement intended to publicize the social doctrine of the church, launched a new magazine, Cité nouvelle, in January 1941 under the direction of Father Gustave Desbuquois (1859-1969). It is soon the principal magazine of the Society. First, it supports the armistice and the policy of national revolution. But doubts appeared in the winter of 1941. The journal was oriented towards philosophical and religious studies, abandoning economic and social issues. At the end of 1942, it embarked on spiritual resistance to Nazism and Communism. Also, the religious establishment of the Jesuit fathers, at Fourvière headed by Father Bremond, ${ }^{8}$ served as a relay for Jewish children and adolescents before their departure to Switzerland. Jewish adults had been hidden as teachers into the college.

During the autumn of 1941, a group of Catholic priests and Protestant pastors in and around Lyon founded a clandestine Christian Resistance journal entitled Cahiers du témoignage chrétien. The initiative came from Father Pierre Chaillet (1900-72), a priest and teacher of German theology and philosophy in the Jesuit school at Fourvière. Father Chaillet, described as a "demanding and reserved intellectual" and later known and honored for his rescue in working with Jewish children, received help and support from the Jesuit Fathers Henri de Lubac (1896-1991) and Victor Fontoymont (1880-1958), and several others

\footnotetext{
7 Dominique Avon and Philippe Rocher, Les Jésuites et la société française (XIXe-XXe siècle) (Toulouse: Privat, 2001).

8 CDJC/I-6o Yagil; La France terre de refuge et de désobéissance civile, 3:150-55.
} 
theologians from Fourvière; also Pastor Roland de Pury (1907-79) from Lyon and two Catholic laymen Alexandre Marc and Louis Cruvillier. ${ }^{9}$ The underground journal was published in November 1941 with a print run of five thousand copies, in which Chaillet and de Lubac had published a principled, theological opposition against Nazism, much along the lines of Pius XII's (r.1939-58) own thinking. Chaillet was a particularly strong supporter of General Charles de Gaulle (1890-1970), since June 18, 1940, the day that the leader of the France Libre (the Free French) made his famous radio broadcast from London.

\section{Father Pierre Chaillet}

Born into a family of farmers, Pierre Chaillet was very marked by his FrancheComté origins. He was ordained a priest in August 1931. During the 1930s, he was a professor in Lyon, and taught fundamental theology also abroad, in Germany, Austria, and Italy. He left Rome with relief because, he writes, "the fascist atmosphere is becoming more and more unbreathable." As an excellent Germanist, he directed his research towards the study of the Tübingen School, an innovative theological current of the nineteenth century, and its leader Johann Adam Möehler (1796-1838). His travels through central Europe and his stay in Germany and Austria confirm him in his awareness of the dangers of Nazi ideology. In 1946, he wrote: "I knew Nazism and its monstrous challenge from the start [...]. I had tried before the war by articles and lectures to disturb the tranquility of the blind and the ignorant."

At the beginning of the war, Chaillet had been stationed in Budapest as a French intelligence officer. He learned about the armistice and decided to return back to France. He arrived in Marseille on December 28, 1940 after a journey from Istanbul to Syria and Beirut, where he embarked on a ship sent from France. As soon as he arrived in Lyon, he was very disappointed to see the climate of general apathy and admiration for Petain, and decided to act. From 1941 to 1944, the Jesuit embraced a double battle, that of truth and charity. In Lyon, he mobilized Catholics during the occupation to help those interned in camps in southern France. He commented on the inactivity of the Catholic Church: "It pains me to note that everything being done to help prisoners and urban refugees is carried out by Protestant and Jewish organizations."10 During

9 Louis Cruvillier was a young militant of the l'Association catholique de la jeunesse française; he was responsible for distributing Témoignage chrétien.

10 YV M31/1770: Pierre Chaillet; Renée Bédarida, Pierre Chaillet: Témoin de la résistance spirituelle (Paris: Fayard, 1988). 
the same months, when Témoignage chrétien was being organized to fight collaboration in general and anti-Semitism in particular, other Christians specifically interested in social and economic assistance to Jews were establishing a body to coordinate their activities and work directly with Jewish welfare agencies. Les Cahiers was the only underground journal in France that pointedly rejected anti-Semitism and countered the authorities' antisemitic propaganda with its own propaganda. This effort, orchestrated by Chaillet, gathered momentum across France and continued until liberation.

The first issue of Témoignage chrétien, a seventeen-page volume entitled France prends garde de ne perdre pas ton âme appeared in November 1941, was written by Father Gaston Fessard (1897-1978), a Jesuit theologian who had denounced the racial laws from his pulpit at Vichy in December 1940. The volume was printed in only five thousand copies and distributed, like all subsequent issues, clandestinely. It declared the fundamental incompatibility between National Socialism and Christianity, denouncing the anti-Semitic campaigns in the collaborationist press and called upon all Christians to make a choice and resist. With regard to the Jewish persecutions, it protested specifically against the internments of Jews at Gurs."1

The year 1942 saw an acceleration of anti-Jewish activity. The summer of 1942 marked a passage in the history of Vichy's anti-Jewish program from its legislative stage to a stage dominated by police actions-roundups, internment, and deportation. Vichy's own initiatives against the Jews and the policy of collaboration with German authorities rendered the position of Christians even more uncomfortable. Meanwhile, on April 2, the return to power of Pierre Laval (1883-1945) inaugurated the period of great dependence on Germans and turned into a more radicalized policy concerning the Jews. Témoignage chrétien published nos. 6 and 7 (April-May 1942) of its clandestine cahiers, entitled "Antisemites" in order to encourage Christians to act against the internment and arrestations of Jews. The number, with a print run of two thousand copies, was a collective effort by Fathers Chaillet, Pierre Ganne (1904-79), de Lubac, and the philosopher Joseph Hours (1896-1963). Father de Lubac, in an important section headed "Antisemitism et conscience chrétienne," stressed that anti-Semitism, totally incompatible with Christianity, meant the abolition of the Old Testament and eclecticism regarding the New Testament, producing a distorted picture of Christ. His publication encouraged Christians to act and help Jews.

11 Charles Molette, Résistance chrétienne à la nazification des esprits (Paris: Éditions OEil, 1998): 137-39; Yagil, La France terre de refuge, 3:53-58 and 150-56; Susan Zuccotti, The Holocaust, the French and the Jews (New York: University of Nebraska Press, 1993). 
In Droits de l'homme et du chrétien, Chaillet described the terrible process of arrests and deportation of Jews: "rafle du Vel' d'hiv" in Paris on July 16, 1942, and revealed that the Vichy regime was preparing to deliver foreign Jews from the unoccupied zone to the Nazis. "The Church can not disinterest itself in the fate of man wherever his inviolable rights are unjustly threatened," he reminded his readers. "When one member of the human race suffers, the entire body suffers with him." Every bishop received a copy of each issue. ${ }^{12}$ What was the real impact of such publication on the attitudes of bishops, nuns, and priests in France and their decision to help Jews is really difficult to precise. But such publications encourage acts of civil disobedience, and initiatives to help Jews by different ways.

While Pierre Chaillet and his followers focused on publishing clandestine reports about Nazi and Vichy policy regarding Jews, they also helped Jews, especially children, escape detention and deportation. In the diocese of Lyon, Chaillet was involved in the establishment of the ecumenical group Amitié chrétienne, in order to assist victims of Vichy government and the German occupation of France. He had dispersed Jewish children among a number of religious houses and provided Jewish refugees with forged papers, as well as helping smuggle Jews into Switzerland. The operation was initially proposed by Gilbert Beaujolin (1914-93), a silk merchant from Lyon, and Olivier de Pierrebourg (1908-1973), a young student. Abbé Alexandre Glasberg (1902-81) and Chaillet soon became involved, Pastor Marc Boegner (1881-1970) and Cardinal Gerlier agreed to be honorary patrons of Amitié chrétienne. Other participants included Jean-Marie Soutou (1912-2009), Germaine Ribière (1917-99), and Annie Langlade among the Catholics and Pastor Roland de Pury (1907-79), Susanne Chevalley (b.1918), and Denise Grunewald among the Protestants were involved in organizing the network. Also involved was Jean Stetten-Bernard (b.1913), who established printing facilities that over the course of three years produced more than thirty thousand identity cards, about fifty thousand ration cards, and thousands of other documents in French and German-all false. Until the German occupation of the southern zone in November 1942, Amitié chrétienne operated openly and legally from its headquarters in Lyon, distributing food and other aid to Jews in and out of the internment camps.

The first rescue efforts were spontaneous and improvised. During the roundup in the Lyon region in August 1942, Jewish children had been parked in a disused barraks at Venisseux outside Lyon. Exploiting the confusion whether or not the children were to be deported, the Amitié chrétienne and Jewish rescue organizations, helped to place the children in safety, despersing them among Catholic families and religious houses. When the perfect Anglei heard

“Droits de l'homme et du chrétien," Cahiers du témoignage chrétien (August, 1942): 5. 
what happened, he asked for the children (about 108) to be given up. ${ }^{13}$ Chaillet refused to divulge the addresses of the Jewish children's hiding places as the police asked him. In consequence, he was placed by the police for two months into a psychiatric hospital in Privas, a town south of Lyon. Cardinal Gerlier himself refused to give addresses of children's shelters to Alexandre Angéli (1883-1962), the regional prefect of Lyon.

We can find other Jesuit priests, in different localities in France. For example, Father Aubé, a Jesuit chaplain of the students in Grenoble, made false papers, thus helping many Jews, and played a considerable role in the distribution of clandestine documents, in particular the issues of Témoignage chrétien. ${ }^{14}$ Aubé, according to Pierre Danchin's testimony, played a very important role in spreading the thought of spiritual resistance. Father Valentin Bachst falsified certificates of baptism intended especially for refugees of the camp of Milles. ${ }^{15}$ As a chaplain at the Milles camp, he succeeded in smuggling a number of interned Jews and especially children. He placed them at the Tour-du-Treuil near Avelard (Isère). Father Gaillard (Benedictine), the parish priest of Voreppe during the war, opposed the Vichy regime from the beginning. He helped the Jews, and without reticence, by giving them false baptismal certificates. He also participated in acts of sabotage on the railways.

\section{The Network of Father Jean Fleury: Poitiers}

Father Jean Fleury entered the Jesuit order at the age of twenty and was ordained a priest on July 10, $1938 .{ }^{16}$ In his capacity as priest, Fleury did daily visits to a detention camp for Gypsies, which was adjacent to a camp for Jews at Route de Limoges. Toward July 20, 1942, he began to devote himself entirely to the help of the Jews by cooperating with Rabbi Elie Bloch, who could not enter the camp. Fleury rescued Jewish children from the camp, and delivered them to local families. By using his close relations with the French underground and its extensive network, Fleury moved the children to the south of France, provided false papers and travel passes, and more than once, money, and food. In

13 Elisabeth Maxwell, "The Rescue of Jews in France and Belgium during the Holocaust," The Journal of Holocaust Education 7, no. 1-2 (Summer/Autumn, 1998): 1-18.

14 CDJC: DCL XXVIII-1/35; Yagil, Chrétiens et Juifs sous Vichy, 135-51.

15 Donna Fryan, The Holocaust \& the Jews of Marseille: The Enforcement of Anti-Semitic Policies in Vichy France (Urbana: University of Illinois Press, 1996), 172-73; CDJC CCXXXVII-54; CCXXXIX-174.

16 CDJC: DCLXXVIII-1; M31/2337 et A.N.72AJ/202 et 203: Vienne; Paul Lévy, Elie Bloch: Être Juif sous l'Occupation (France: Geste Éditions, 1999); Paul Levy, Un camp de concentration Français: Poitiers 1939-1945 (France: SEDES, 1995); Yagil, La France terre de refuge, 3:136-41. 
the end, he was responsible for saving at least one hundred Jews and for assisting in various ways another thousand. The activity of Fleury was well known by other persons who helped Jews in this department. This was the case of Hélène Marzellier (b.1915) who lived in Poitiers, in the German-occupied zone.

From 1942 to 1944, she was a senior clerk at the prefecture and therefore had prior knowledge of plans to arrest local Jews. She used this sensitive information to warn targeted Jews in advance. Along with her colleague Jeannette CaillaudFayolle, Marzellier warned Jews personally or through liaisons, and cooperated with Fleury, in his systematic rescue efforts. In late September 1943, Marzellier warned Régine Breidick, the secretary of Rabbi Élie Bloch, after finding her name (and the names of her brother and sister, Jacques and Jeanne) on a list of Jews in Poitiers whose French citizenship had been revoked. Aware that the three Jews faced arrest, Marzellier rushed to Breidick's home, warned of the imminent danger, advised immediate flight, and told her to warn her brother and sister. She obtained a false identification card for Régine with the help of Fleury's assistant. Thanks to her prompt action, the three Breidicks escaped and survived. Marzellier, who ran great risks, never sought a reward for these rescue operations; she was motivated only by humanitarian concerns. ${ }^{17}$ Father Marcel Bith (1883-1963), a Jesuit from Poitiers, helped Fleury and his network composed by: Suzanne Bourlat (b.18go), Marcelle Deschamps (b.1922), Marcelle Poirier (b.19og), and others, to hide Jewish children and take charge of them. Father Leprat, a professor at the Collège Stanislas in Poitiers, with the support of Pierre Planquet, organized near the line of approach a path to allow Jews to pass through the free zone. The sector had gradually transformed itself into an escape route to Spain for Allied aviators and French volunteers. ${ }^{18}$ The chaplain of students, Father Robert Hamel (d.1974), a Jesuit, worked to save the Jews and had to leave Poitiers to be forgotten in December 1943. The peasants of the region also helped to save lives by rendering services or hiding for a few nights the young people in their house.

\section{Father Roger Braun and the Network in Toulouse}

Roger Braun was born in 1910 in Paris, and became a Jesuit priest in Toulouse in $1929 .{ }^{19}$ Because of his Alsatian origins, he became aware from his youth of

\footnotetext{
17 Yad Vashem, M31/1484.

18 A.N.72AJ/203; La Croix (November 1984).

19 M31/762 et CDJC/ DCLXXVIII-1/22; Yagil, La France terre de refuge, 3:92-120; Jean Guitton, Le Cardinal Saliège (Paris: Grasset, 1957).
} 
the drama of anti-Semitism. He had taken care of the Spanish refugees at Lyon, and after completing his Jesuit priestly training in Lyon at Fourvière, he was appointed by Cardinal Gerlier as a chaplain in the internment camps in southern France, side by side with representatives of Protestant and Jewish rescue organizations. This position enabled him to remove children and women clandestinely from several camps in southern France. He obtained false documents and ration cards and distributed them to those in need. In 1942, Braun was appointed chaplain of the detention camps of Gurs and Rivesaltes in southern France. Henri Schilli (1906-75) was then the rabbi of those two camps, and he witnessed the actions of the Jesuit. To help the Jews detained in camps, he worked hand in hand with most of the Jewish relief organizations, with rabbis, and with other Jewish leaders. He worked also with the help of Father Lagarde in charge of the general chaplaincy of the internment camps for foreign refugees in France, Monsignor Louis de Courrèges d'Ustou (1894-1979) and a few non-religious people.

This network, composed of a large number of Jesuits, also had important ramifications in the Limousin region, particularly in Limoges. Braun hid the fifteen pupils of the rabbinical seminary led by the young Chief Rabbi Abraham Deutsch (1902-69) in Limoges. ${ }^{20} \mathrm{He}$ also cooperated with Amitié chrétienne in Lyon to assist persecuted Jews. In November of that year, when the Germans occupied southern France, Braun opened a branch of Amitié chrétienne in Limoges and maintained contact with the Organisation de secours aux enfants (OSE), which took care of Jewish children. He did so in cooperation with Protestant organizations and Jewish underground movements. Thanks to his networks, he was able to help Jewish prisoners and even free some of them. Thus, in September 1942, Braun persuaded the commander of the Rivesaltes camp not to deport thirty Jewish children, but rather to entrust them to Secours Suisse. Clandestinely, he multiplied contacts with the rabbis and organized the rescue of Jewish children especially to Switzerland and Spain, and contributed to hide Jews in Catholic establishments. Despite the constant danger, Braun devoted all his efforts during the occupation period to the rescue of Jews. After the war, he continued his activities on behalf of Jews and founded Rencontres judéochrétiennes, a French movement that promoted Christian-Jewish encounters. ${ }^{21}$

Braun succeeded in placing many people among the Little Sisters of the Poor and especially Jewish children at the orphanage of Grande-Allée. Among the Redemptorist fathers, all the refugees, Jews and non-Jews, could find a warm welcome, and the Trap of Saint Mary of the Desert was transformed into

\footnotetext{
20 CDJC: DCLXXVIII-1

21 Archives de Vanves: Papiers Braun: T24/16-18.
} 
a haven for anyone worried by French laws or by the occupying authorities. The priests were involved in hiding Jews. Father Lagarde, chaplain general of the French internment camps and foreign workers' groups, succeeded in removing from the various internment camps about $65^{\circ}$ people, most of whom were over sixty years of age (almost all Jews), and he placed them in about forty public or private hospitals. Places were found in the hospitals of the free zone and the hospitalization of these people was partially paid by the state of Vichy, the Catholic Committee, the CIMADE, and later by the U GIF . ${ }^{22}$ In fact, the network that was organized was composed by Jesuit priests, and other religious and non-religious people in the diocese of Toulouse. Most of those initiatives were encouraged by the bishop, Mgr. Jules-Géraud Saliège (1870-1956). The Jesuits of the House of Works in Perpignan facilitated the passage to Spain of Jews and other fugitives. The organizations of the Resistance found real help with Father Jean Bousquet, in Saint-Laurent de Cerdans. He is known for his humanistic commitment during the Retirada, having opened the chapel Notre-Dame-dela-Sort to the wounded and the parish church to the refugees. ${ }^{23}$

\section{Avignon Network}

The Collège Saint-Joseph in Avignon, like many other colleges and institutions of free education in Marseille, and Avignon, accepted Jewish pupils with greater ease and the Jewish professors, expelled from the secular schools, could be engaged. Since September 1940, the school gave asylum to two escapees from the occupied zone whose family was dangerously hunted down, and thereafter the same service was given to three young Jews. As early as 1943, the college became a center of resistance thanks to the activities of Father Jean Roche (1900-88), rector of the college who helped the Ajax, resistance network by making available to the network his office and the premises he needed. They served as "mailboxes." 24 Jesuits of the college and in the department of Vaucluse

22 Noël Bayon, Le Grand Q. G. de la charité: Le Secours catholique (Paris: Fayard, 1955). CIMADE was founded in 1939 by French Protestants in order to give assistance and support to refugees and later to Jews. UGIF (Union Generale des israelites de France) was an organization established by the Vichy government's office of Jewish Affairs to consolidate the Jewish organizations of France into one single unit. The UG IF was set up on November 29, 1941 in response to German demands.

23 Emilienne Eychenne, Les Portes de la liberté: Le Franchissement clandestin de la frontière espagnole dans les Pyrénées-Orientales de 1939 à 1945 (Toulouse: Privat, 1985), 79-80; Yagil, La France terre de refuge, 3:87-105.

24 A.N.72AJ/73; Collège des jésuites Avignon 1565-1950: Centenaire du Collège (Avignon: [Sadag], 1950): $5^{6-75}$. Yagil, Chrétiens et Juifs, 249-52. 
spread information concerning the danger of Nazism and persecutions against Jews and other people in Germany. At the Immaculate Conception in Avignon, at the Clarissa de la Verdiere, at the Saint Joseph College in Avignon, at the Convent of the Sacred Heart, and at the Aigues Tower Boarding School, the Jews found a haven in this period. At the Maternity Hospital of Sainte-Marthe d'Avignon, the director Ms. Lauze Madeleine, hid Jewish children in the establishment. Father Marcel Roy, vicar of Cavaillon, and Father Joannès Delorme of the Tour d'Aigues collaborated with others such as François Demoulin, Jean Longchambon, Yvonne Dumas, Simone Mathevet, and Ms. Michallet, in order to securely place Jews. Pastor Pierre Rouger hid Jews with the help of Canon Delorme and the Jesuit Jean Roche. With him, also acted a group of professors composed by Robert Maddalena, ${ }^{25}$ Belle-Larant, Saussard, Denziot, and Father Martin. The group diffused Témoignage chrétien and produced identity cards and false papers, the transmission of information for intelligence services (close liaison with the Ajax group), and the accommodation of officers of that service.

Maddalena assisted Jewish children and their parents who were hunted down by the Vichy police and the Gestapo after the total occupation of France. He helped by registering Jewish children on baptismal registers, issuing false identity cards and falsifying other documents, and helping to find places of refuge to hide. The first markedly Catholic resistance newspaper La Voix $d u$ Vatican (The voice of the Vatican) appeared in July 1940. The Jesuit college in Avignon had taken the initiative to reproduce duplicates and distribute the French broadcasts of the Vatican Radio. ${ }^{26}$ These were provided by Emmanuel Mistaen, a Belgian Jesuit who appeared in his speeches not to have resigned himself to the defeat of France and the political consequences of Vichy. From July to October 1940, Catholics linked to the Jesuit college of Avignon spread among their entourage Cahiers de témoignage chrétiens composed of three to six pages. The extension of the network was based on the friendships among sillonistes and popular democrats, from Henri Barral in Avignon to the notary Marseille Jules-Léon Perrin whose son, Jules-Xavier, activist of Catholic Action and a resistant, is linked to a lively Marseille group organized by the Dominicans, Boulogne and Joseph-Marie Perrin $\left(1905^{-2002}\right) .^{27}$

Other networks and resistance movements were established in Marseille during 1941: Combat, Alliance of Marie Madeleine Méric Fourcade (1909-89) linked to the Intelligence Service (IR), Carte created by the painter André

\footnotetext{
25 Yagil, La France terre de refuge, 1:313-14.

26 Renée Bédarida, "La Voix du Vatican (1941-1944): Bataille des ondes et résistance spirituelle," Revue d'histoire de l'Église de France 173 (1978): 215-43. 
Girard (1901-68), and Brutus created by Colonel Pierre Fourcaux (1898-1998), as well as channels for the relief of Jews, on the Protestant or Catholic side, and that of charitable organizations. ${ }^{28}$

\section{Tours-Angers}

Many religious congregations were represented in Touraine: contemplative communities such as the Carmelites or active women like the Daughters of Charity, the Little Sisters of the Poor or the Nuns of the Presentation of the Blessed Virgin, the Jesuits, and the Capuchin order. The authority of the archbishop also extended to many private schools and secondary schools, including the Collège Saint-Grégoire directed by the Jesuits or the Petit Séminaire. The Great Seminary, which had become a training center for future priests, had about thirty pupils in 1940. About two thousand people had been rescued thanks to Abbé Henri Péan (1874-1944). He was a curate by day and a ferryman by night. He was also an intelligence officer who was a member of several Resistance networks: Marie-Odile, Marie-Claire, Libé-Nord, and the Jade-Amicol network, part of the Intelligence Service. This network had been born in Bordeaux, at the home of the Jesuit Father Antoine Dieuzayde (1877-1958), a singular awakening of consciousness animating many youth movements. Father Péan assisted him. He was arrested on Sunday February 13, 1944 by the Gestapo. Also, Father Bernard de La Perraudière (1898-1981) created in 1940 a group of resistance to Nazism. Born in 1898, he entered the Society of Jesus in 1920 and was ordained a priest in 1930. He was profoundly influenced by the war of 1914. Inspired by Christian values, and especially by the pope's encyclical of March 1937, Mit brennender Sorge, which encouraged resistance to racism and national-socialist ideology and policy. De La Perraudière was informed about the persecution of Christians in Austria and Germany. He was a prisoner in 1940. Having escaped, he entered the Resistance, in the CahorsAsturies Resistance network and was among the first to diffuse Témoignage chrétien in 1941. He often lodged at the Carmel street of the Ursulines, with the complete complicity of the principal superior who had all these fugitives, and served them meals in the framework of the Entraide française. The Carmel of Tours was located right next to the student house where de La Perraudière lived. Knowing well the humane values of the nuns, he knew that they could be trusted. Then, he made them pass the line or orient them in pathways that he

28 For more information, see Yagil, Chrétiens et Juifs, 249-51; Jack Vivier, Prêtres de Touraine dans la Résistance: Soutanes noires, soutanes vertes (Chambray: CLD, 1993), 49-57. 
knew well: the family Mary and Doctor Voisin at Ligueil, Abbé Péan at Draché, Maurice Genest at Tours, Jacques Borgnet, the Goupille family from La HayeDescartes, ${ }^{29}$ and Colonel Marnet from Tours. Arrested by the Gestapo in 1943 , de La Perraudière was sent to Dachau. He returned to France after $1945 .^{30}$

\section{The Network in Paris}

Emmanuel Suhard (1874-1949), the Catholic cardinal archbishop of Paris had taken up his post on May $18,1940 .{ }^{31}$ His palace was searched, as was the residence of Cardinal Alfred Henri Baudrillart (1859-1942) at the Institut Catholique, and he was placed under armed guard. Like many members of the Catholic Church, he refused to speak out publicly lest he draw attention to the Jews who had thus far been spared, and perhaps also because he did not want to cause rifts within his own confession or with the Germans by pursuing the issue too far. This led to post-war criticism, but it has also been argued that he used his position to help those interned in Drancy and Pithiviers camps since 1941—sometimes with success. On July 22, 1942, Cardinal Suhard of Paris, writing on behalf of the French Assembly of Cardinals and Archbishops (Assemblée des Cardinaux et Archevêques), sent a protest note to Pétain in reaction to the Paris arrests of Jews on July 16 and 17, 1942. This letter of protest, which was composed in sharp and emotional words and was addressed to the supreme representative of a regime that regarded the Catholic Church as one of the mainstays of its rule, had its intended impact. Moreover, he was directly responsible for helping Jewish children find hiding places under false names in Catholic educational institutions and orphanages and also organized social services for those in internment camps. ${ }^{32}$ In fact, many religious institutions in Paris, such as Sisters of the Visitation, the Carmelites, Sisters of Saint Thomas de Villeneuve, Sisters of Saint Vincent de Paul, Orphelins d'Auteuil, Religieuses de Sion, Franciscan missionaries, Soeurs de la doctrine chrétienne, Religieuses de Marie Auxiliatrice et Filles de la Charité, have accepted to hide more than three hundred children. They organized a network for hiding children and

\footnotetext{
29 Éric Alary, La ligne de démarcation 1940-1944 (Paris: Presses universitaires de France, 1996); Yagil, La France terre de refuge, 2:272-73.

30 Limore Yagil, Sauvetage des Juifs dans l'Indre-et-Loire, Maine-et-Loire, Mayenne, Sarthe, et Loire-Inférieure 1940-1944 (La Crèche: Geste Éditions, 2014).

31 Archives de l'Eglise, dossier cardinal Suhard; Charles Molette, Prêtres, religieux et religieuses dans la résistance au nazisme 1939-1945: Essai de typologie (Paris: Fayard, 1996).

32 Yagil, Chrétiens et Juifs sous Vichy, 518-21.
} 
Jewish families. They were using their contacts in religious institutions across the country or within peasant families in departments outside Paris, such as Sarthe, Mayenne, Nièvre, etc.

Father Théomir Devaux (1885-1967), head of Fathers of Notre-Dame-deSion, was involved in finding false papers and hiding places for those in danger of deportation..$^{33}$ This foundation had been a centre for ecumenical discussion since his arrival in 1925 and had published La question d'Israël, a revue that had a marked anti-Nazi tone. As early as 1940, it was a target for the Gestapo, and their agents searched the building and confiscated the archives in order to stop any further publications. Nonetheless, in spite of being known as an opponent, Devaux became ever more involved in helping Jews, both adults and children. Thus, as early as 1941, he was engaged in finding false papers and hiding places for those in danger of deportation. Using his contacts within the church, he was able to place children in religious institutions across the country or with peasant families. The Convent of the Sisters de Notre-Dame-de-Sion, had some of its building requisitioned by the Germans in 1940 and had been in danger of being closed as a reprisal for the singing of an anti-German hymn in praise of Joan of Arc (1412-31) in 1942.

In fact, it was saved only by Suhard's direct intervention, but became the headquarters for the publication of Les Cahiers du témoignage chrétien. It had not only actively condemned the anti-Semitism of the Vichy regime but also mounted a critique of the Catholic Church — and therefore of its hierarchy — for not having done more to help the refugees and those sought by the Germans. ${ }^{34}$

We can mention also Father Daniel Pézeril (1911-86), ${ }^{35}$ who was appointed vicar of the St. Etienne du Mont Church in Paris in 1941 and together with other Catholic priests and students, issued more than a thousand false certificates of baptism, especially for Jews. Particularly noteworthy is the contribution of the Jesuit fathers of Haxo Street, Father Henri Diffiné ${ }^{36}$ and Father Emile Joseph Marie Planckaert who, together with Mlle. Loucheur, worked to supply the Jews with the help of those who could escape false identity papers, and to help them by various means. ${ }^{37}$ In 1943, Father Planckaert succeeded in

33 YV M31/7245: Théomire Devaux; Archives des Religieux de Notre-Dame de Sion à Paris: Dossier Father Devaux; Yagil, Chrétiens et Juifs, 521-23.

34 Yagil, Chrétiens et Juifs, 518-21; Cointet, L'Église sous Vichy, 293-98.

35 Pézeril was recognized as Righteous among the Nations by Yad-Vashem in 1986.

36 Marc Flichy, Diffiné: Fils du bon Dieu, fils du bon peuple (Paris: Edition Téqui, 1982); François Graffin, Henri Diffiné 1890-1978, prêtre de la Compagnie de Jésus: Mystique et guide spiritual (Paris: Havas, 2000): 169-70.

37 Riquet Michel, Chrétiens de France dans l'Europe enchaînée: Genèse du secours catholiques (Paris: s.o.s., 1973), 95-115; Anny Latour, La résistance juive en France 1940-1944 (Paris: 
penetrating into the Drancy camp, and succeeded in bringing several Jews out of the camp, supplying them with false papers and finding refuge among private persons or in convents. He helped Father Théaumir Devaux to save Jewish children. This activity was particularly risky. Let us recall that the pastor of Saint-Germain-des-Prés, Chanoine Lancrenon (1886-1961), was arrested by the Gestapo on May 25, 1941 for organizing a chain that manufactured false papers for escaped prisoners with the help of the mayor's office. ${ }^{38}$ The young Jesuit Jacques Sommet, a student at the Sorbonne and Sciences-Po, participated in 1942 in a network hiding Jews and organized passages in Spain. He also distributed the publications of Témoignage chrétien.

Father Michel Riquet gave the example of a rebellious and disciplined churchman. ${ }^{39}$ The study of Riquet's action and thought is revealing to us in understanding the journey of the churchmen who had the courage to disobey under certain circumstances. His trajectory, that of a Jesuit father, is doubtless rather paradoxical. Michel Riquet was born in 1898 in Paris in the 14th arrondissement. His father was a painter and worked as a decorative artist. He had decorated the wagon where the Armistice of 1918 was signed. His mother was a native of Amiens. She was a musician and played the piano. During the war of 1914-18, the Riquet family lived in Versailles where artists mobilized and regularly came to sing at their homes. Living in a bourgeois and very religious family, the young Riquet was influenced like many of his generation by Charles Maurras (1868-1952) and the Action Française. Enthusiastically inspired by the philosophy of Thomas Aquinas (1225-74), he decided in 1918 to enter the novitiate of the Society of Jesus in Beaumont-sur-Oise, not far from Paris. Influenced by his teacher Jacques Maritain (1882-1973), he became a fervent Thomist.

With him, he participated in the organization of the demonstrations of the Catholics of Anjou against the secular laws decided by the government. He published in the review Études two important articles concerning the right of resistance to oppression. During his passage in Lyon at the scholasticate of Fourvière, he had seconded his friend Maritain in his defense of Pope Pius XI (r.1922-39) against the attacks of Action Française. As a pupil and disciple of Maritain, he had engaged in various missions for the refugees of Austria, Spain, and the various victims of fascism and Nazism. Ordained priest on August 28, 1928, he became director of the Laënnec Conference in Paris, an association of

Stock, 1970), 48-55.

38 Fonds Suhard 1D XIV-19: témoignage du chanoine Lancrenon du 31 mars $195^{8}$.

39 Archives Jésuites à Vanves: Fond Riquet: Box $\mathrm{N}^{\circ} 5$ to 42 ; Michel, Chrétiens de France dans l'Europe enchaînée; Yagil, La France terre de refuge, 3:146-48. 
Catholic medical students, who acted in conjunction with various solidarity groups during the 1930s. Many of the young physicians enrolled at the Laënnec Conference occupied important positions in hospitals and faculties, and even in municipal and general councils. The main idea was to make the Laënnec Conference the melting-pot of a Christian medical elite. Most of those who have frequented this circle were penetrated with a Christian spirit for a better service of man and were more apt to disobey laws and to rescue Jews or other categories of proscribed people during the occupation. It was an important network of several thousand people in hospitals, clinics, dispensaries, hospices, congregations, etc. It was in the encyclical Mit brennender Sorge that Riquet and his friends found the justification of their attitude. ${ }^{40}$

In 1938, Cardinal Verdier instructed him to coordinate the various reception works for Spanish refugees and those from central Europe, including many Jews, at the French Catholic Relief Committee. At the request of Verdier, various congregations placed their orphanages and other institutions at the disposal of thousands of children, women and elderly Basque refugees, Catalans, as well as countries occupied by Nazi Germany. They will also have the attitude from 1940 on toward Jewish children and adults. As early as 1940, Riquet developed networks and channels whose members shared the urgent desire to educate Parisian students against the dangers of Nazism and racism and engage them in aid and rescue activities especially concerning Jews. Riquet contacted the Combat resistance movement as early as 1941. His office in Assas Street became an important center for resistance. Riquet clearly encouraged resistance to Nazism and the defense of the Jews. This message was duplicated in hundreds of copies and distributed. Riquet was particularly involved in the activity of the Comète network, which was in charge of reception and escape of aviators. Arrested, Riquet was deported to the camp of Mauthausen (1944), then to Dachau (1945) until the liberation of the camp when he came back to France.

The French Jesuit theologian, Yves de Montcheuil (1900-44), was executed by the Nazis in Grenoble, because he was involved with French Resistance fighters in the Maquis (rural guerilla) against Nazi occupation during World War II. In responding to their call, those of young Christians without the sacraments, Montcheuil joined them for a short stay in July 1944. The Germans attacked a few days later and he was captured in a cave with doctors, nurses, and their patients. multibiographie, vol. 2: Les revenants (Paris: Seuil, 1992), 354-55; Yagil, La France terre de refuge, 121-28. 
De Montcheuil provided the spiritual resistance of the French church to Nazism with major theological impetus and practical assistance. De Lubac, writing in 1987, nevertheless described him as "almost forgotten," while historian Étienne Fouilloux in 1995 referred to his progressively declining theological influence over the preceding quarter century as a "second death." ${ }^{41}$ Born in 1900 in Paimpol on the northern coast of Brittany, Montcheuil attended a Jesuit college in St Helier on Jersey and entered the Society of Jesus in 1917, remaining in St Helier at the Maison Saint-Louis. This was an exile: clergy and members of religious orders were not permitted to teach in French schools following the 1902 Combes legislation secularizing the education system, and parents who wanted their children to have a religious education had to send them abroad, often to religious communities in exile. In 1919, Montcheuil commenced his Jesuit training in Canterbury, which was interrupted by two years' compulsory military service in France. Having earned a licentiate in philosophy from the Sorbonne, in 1934, following four years of theological study in Lyons, he received a doctorate from the Gregorian University in Rome. He had taught at the Catholic Institute of Paris, and was influential in developing a pioneering theology of action. His experience of serving as a chaplain to the Young Catholic Workers movement was influential in this. His writings and theology were heavily influenced by the work of Maurice Blondel (1861-1949). In his most important work, L'Action, Blondel developed a "philosophy of action" that integrated classical Neoplatonic thought with modern Pragmatism in the context of a Christian philosophy of religion. ${ }^{42}$ De Montcheuil was also a close friend of de Lubac, who would play a significant role at the Second Vatican Council. A turning point in his life was when Paris fell to Hitler's army in June 1940. The most noteworthy project to which de Montcheuil contributed was the distribution of the Cahiers du témoignage chrétien. De Montcheuil was unable to take part in the journal's foundation because he was living in France's occupied zone, but he fostered secret distribution networks for the Cahiers in Paris and the occupied north. The Cahiers disseminated reliable information about the occupation of France and the Nazi genocide elsewhere, encouraged and

41 Renée Bédarida, "Théologie et guerre idéologique," in Henri de Lubac et le mystère de l'Église, ed. Michel Sales et al. (Paris: Cerf, 1999), 216-17. Henri de Lubac, Three Jesuits Speak: Yves de Montcheuil, 1899-1944; Charles Nicolet, 1897-1961; Jean Zupan, 1899-1968 (San Francisco: Ignatius, 1987), 32; Étienne Fouilloux, Yves de Montcheuil: Philosophe et théologien jésuite (1900-1944) (Paris: Médiasèvres, 1995), 45; Yagil, La France terre de refuge, 3:30-33.

42 See Maurice Blondel, L'Action: Essai d'une critique de la vie et d'une science de la pratique (Paris: Alcan, 1893); trans. Oliva Blanchette as Action: Essay on a Critique of Life and a Science of Practice (Notre Dame, Ind.: University of Notre Dame, 2003), 76-77. 
exhorted French Christians to conscientious witness, and provided accurate versions of papal pronouncements, which in newspapers were subject to heavy censorship if they appeared at all.

The editors of the Cahiers also acknowledged the important role of Vatican Radio - in de Lubac's phrase, the "true older brother of the Cahiers" - in this task. ${ }^{43}$ Under the director of its French section, Father Mistaen, the station disseminated both radio broadcasts and, from Marseille, printed texts of the most significant papal statements. The Cahiers included news of resistance to Nazism in other European countries, as well as excerpts from the inspirational writings of Karl Barth (1886-1968), disseminated from his retreat in Basel. In particular, the second issue included extracts from a long letter of Barth's to French Protestants, in which he proclaimed:

Faced with the troubles and obligations of our times, we may not remain as outsiders or spectators. Even those who would like to remain neutral with respect to them, in reality are not. [...] War brings people to a point of clear decision: a "yes" or a "no," along with all its consequences. We are all implicated in this opposition, we are all responsible for its birth and existence; and all of us, from one side of the divide or the other, participate in [Nazism's] abolition, whether by collaboration, active participation, guilt, or as victims. ${ }^{44}$ The Cahiers, while Catholic directed, thus promoted an ecumenical witness against Nazism.

\section{Conclusion}

The history of the Society of Jesus oscillates between the singularity of each of its foundations, the influence of certain personalities, and the universalist vision of its project. The case of Lyon is particularly representative of this ambivalence between the particular and the universal, between Jesuits who obey and respect the Vichy regime, and those who take initiatives in order to rescue Jews. The engagement of many men religious in acting for rescue of Jews, was most of the time the direct consequence of their capacity for civil disobedience as individuals to act in different ways. Catholic rescue, it appears, as compared with Protestant rescue often emerged from a culture that included personal

43 Renée Bédarida, "La Voix du Vatican (1940-1942): Batailles des ondes et résistance spirituelle," Revue de l'histoire de l'Église de France 64 (1978): 215-43.

44 Karl Barth, "Une question et une prière aux Protestantes de France," Cahiers du témoignage chrétien 2 (January 1942). 
friendships with Jews. Sociological and social anthropological studies of rescue have been primarily concerned with interrogating and understanding the role of individuals. As a result, the role of organized networks has often been downplayed. The creation of networks could come through many different channels: political, educational or neighborhood, but all usually required an individual driving force. The practical matters associated with hiding Jews; the identification of hiding places, the provision of food, ration cards, and identity documents was taken on by the network. Generally the bishop approached the directors of welfare institutions, rectors, and headmasters of schools as well as the priests and mother superiors of religious houses to provide aid and hiding places. Many Jesuits and Dominicans priests were involved in different networks around France. Clerical influence was often crucial, but this should not be allowed to undermine the existence and importance of secular organizers and the problems they faced in finding individual hiding places, even when supported by local clerics and community leaders. Support for Jews in hiding was also assisted by the creation of networks to help labor draft evaders, but across Western Europe, these developments came too late to help the majority of Jews.

The story of the rescue of Jews in Paris shows how the individuals and organizations were motivated by humanitarian concerns, religious conviction, and civil disobedience. Approximately 250,00o Jews living in France in 1940 survived the war. About thirty thousand lived openly in Paris, wore the star, obeyed all regulations, went out as little as possible, and survived with a good dose of luck. Another fifty thousand at least escaped to Spain or Switzerland. Twenty to thirty thousand, mostly children, survived with the help of Jewish rescue organizations and especially Catholic and Protestant networks that placed them with non-Jewish hosts. The largest group of Jews in France, however, about 140,000 to 150,000, survived in some form of hiding with little organized help. Finally, men and women of the church had both religious and secular contacts over a large area and knew where to look for help in obtaining hiding places, false papers, extra food, and guides. Thus, informal rescue networks of people who knew and trusted one another sprang up naturally and quickly.

Although Resistance against Nazism has become one of the modern archetypes of liberating violence and one of the founding myths of European societies, it is important to distinguish between civil disobedience and civil resistance. In fact, the phenomenon of rescue is not always related to Resistance. Generally, it includes individuals trying to organize themselves locally in order to bring aid and assistance to persecuted individuals such as Jews. Obviously, individual and institutional behaviors varied inside the country between 
different regions and during the periods of war. In other words, although one can indeed observe mixtures of collaboration, accommodation, dissidence, and resistance in the behavior of various populations, we must also take into account the general state of the civil disobedience of individuals. ${ }^{45}$ This study also shows the important influence of the encyclical Mit brennender Sorge of March 14, 1937. This well-known encyclical was drafted in a particularly tense environment, with the Vatican engaging in in-depth contemplation on racism and rationalism, in particular in relation to the Holy Office. Alfred Rosenberg's $\left(1893^{-1946)}\right.$ book was placed in the Index in $1934^{46}$ The encyclical was certainly one of the strongest and most courageous documents issued by the Holy See deploring National Socialism. ${ }^{47}$ In 1940 , in the case of the Jews, the Vatican recognized ethnic but non-racial peculiarities. This anti-racist attitude calls people to be charitable and humane towards them. In fact, in France, for many bishops, priests, and sisters, the encyclical encouraged them to act and rescue Jews, even if Pius XII did not speak openly about it. Christians were encouraged to obey their consciences and disobey rules, in order to rescue Jews. In fact, many Jews were being rescued by Catholic institution or individuals. It was actually a lower echelon of bishops and other activists who quite clearly took initiative. This study reveals much about the phenomenon of Jewish rescue during the Holocaust in France, where the church was very influential within society.

There were a total of six of these indignant messages, which reflected the reawakening of the Christian conscience, written by three archbishops and three bishops. From August 23 until September 20, 1942, Monsignor Saliège, archbishop of Toulouse, followed by Monsignor Pierre-Marie Théas (1894-1977), bishop of Montauban, Monsignor Jean Delay, bishop of Marseille (1879-1966), Cardinal Gerlier, archbishop of Lyon, Monsignor Edmond Vanstenberghe of Bayonne (1881-1943), and Monsignor Jean-Joseph Moussaron (1877-1956), archbishop of Albi, wrote messages to be read out in their churches. Of course the number of episcopal protests may seem to be negligible-six, at a time when there were around a hundred bishops in France. But their impact was considerable, because the denunciation of the brutality of the roundups was equivalent to an attack on the entire system of brutal

45 Limore Yagil, "Rescue of Jews: Between History and Memory," HJSR 28, no. 2 (2004): $105^{-40 .}$

46 The reference is to Alfred Rosenberg, Der Mythus des 20. Jahrhunderts: Eine Wertung der Seelisch-Geistigen Gestalmtenkämpfe unserer Zeit (Munich: Hoheneichen-Verlag, 1930).

47 Jean Dujardin, L'Église catholique et le peuple juif: Un autre regard (Paris: Calmann-Lévy, 2003), 190-92. 
persecutions and deportations. But many Catholics, like the Jesuits, had not waited for the bishops' statements of the summer of 1942 to hear the voice of conscience; they had already rejected the poison of Nazi ideology and provided assistance and shelter to persecuted Jews. The Jesuits, as well as the Dominicans all over France, performed many similar acts of charity and helped Jews to survive. The Jesuit order provided hiding places for several hundreds of children; and, all told, more than 120 priests were deported for the "crime" of hiding children in their houses. 